\title{
Analisa Efisiensi Water Tube Boiler Berbahan Bakar Fiber dan Cangkang di Palm Oil Mill Kapasitas 60 Ton Tbs/Jam dengan Menggunakan Chemicalogic Steamtab Companion Version 2.0
}

\author{
Khaidir Maulana ${ }^{1 *}$, Lukman $^{2}$, Faqih Burhanuddin ${ }^{3}$ Ari Susandy Sanjaya ${ }^{4}$ \\ 1,2,3,4 Program Studi Teknik Kimia, Universitas Mulawarman J1. Sambaliung No.09 Kampus Gunung Kelua \\ Samarinda, 75119 \\ *email: khaidirm23@gmail.com
}

\begin{abstract}
Some of the factors that occupy the efficiency of the boiler are superheater pressure, feed water temperature, steam temperature, the amount of steam produced, the amount of fuel consumption, and the calorific value of fuel combustion. ChemicaLogic Steamtab Companion Software is software that use to calculate enthalpy value. The purpose of this research is to get the relationship of variation of superheater pressure with boiler efficiency, variation of feed water temperature with boiler efficiency, variation of steam generated with boiler efficiency, analyzing fuel calorific value of $75 \%$ fiber $+25 \%$ shell and analyzing water tube boiler. From the analysis result that has been done, the relation of variation of superheater pressure with boiler efficiency is not constant but irregular or up and down, the relation of feed water temperature variation with boiler efficiency is not constant but irregular or up and down, the relation of variation of steam produced with boiler efficiency relatively up. The highest burning calorific value (HHV) is 21078,4853 kJ/kg. The lowest burning calorific value (LHV) is 17838,4853 kJ/kg, the highest boiler efficiency value generated is $54.7 \%$ and the lowest boiler efficiency amounting to $44.23 \%$.
\end{abstract}

Keywords: Boiler, Burning Calorific Value, Boiler Efficiency, ChemicaLogic Steamtab Companion

\section{Pendahuluan}

Indonesia memiliki potensi besar untuk memanfaatkan produk samping kelapa sawit sebagai sumber energi terbarukan dan berkelanjutan khususnya Kalimantan Timur tepatnya dibagian Kutai Timur, Sangkulirang. Demikian pula dengan halnya PT. Indonesia Plantation Synergy yang bergerak dibidang agro industri menggunakan sumber energi biomassa limbah kelapa sawit. Sumber energi biomassa yang digunakan adalah berasal dari limbah padat pengolahan. Limbah tersebut yang akan digunakan sebagai bahan ketel uap. Pemanfaatan biomassa fiber dan cangkang secara optimal sangat berguna dalam hal peningkatan efisiensi boiler dan akan digunakan berguna untuk menganalisa sistem kerja boiler [1].

Boiler mempunyai peranan yang sangat penting dalam kelangsungan kinerja dari sebuah pabrik kelapa sawit dengan kata lain bisa dikatakan sebagai jantung dari pabrik kelapa sawit. Fungsi dari Boiler adalah menghasilkan uap yang digunakan untuk kebutuhan proses pabrik, dan membangkitkan listrik untuk kebutuhan pabrik maupun perumahan karyawan di sekitar pabrik [1]. Uap keluaran turbin digunakan untuk proses pengolahan, di Palm Oil Mill dimana uap dibutuhkan untuk stasiun perebusan (sterilizer), stasiun press (digester), stasiun klarifikasi, stasiun pengolahan inti sawit, dan stasiun tangki timbun [5].

Banyak pabrik atau perusahaan yang sudah menerapkan pengunaaan bahan bakar alternatif. Dan saat ini P.T. Indonesia Plantation Synergy memiliki kapasitas 60 ton TBS/jam. Analisa bahan bakar yang digunakan pada boiler P.T. Indonesia Plantation Synergy adalah fiber kelapa sawit murni, cangkang kelapa sawit murni serta fiber $75 \%$ dan cangkang 25\% [5]. Disamping itu sering kali efisiensi kualitas kerja Boiler tersebut diabaikan padahal peningkatan efisiensi kualitas kerja Boiler itu sendiri akan memberikan nilai ekonomis sendiri bagi perusahaan. Oleh karena itu peningkatan efisiensi Boiler sangat penting guna mendapatkan output yang baik [5]. Oleh karena itu perlu adanya analisa mengenai kinerja dari Boiler di perusahaan kelapa sawit dengan mengkaji lebih dalam sehingga dapat mengetahui kondisi optimum dari kinerja efisiensi Boiler menggunakan simulasi ChemicaLogic Steamtab Companion versi 2.0 [3].

Tujuan dari simulasi ini adalah untuk mengetahui nilai efisiensi water tube boiler di Palm Oil Mill tertinggi dan terendah, membandingkan efisiensi water tube boiler saat baru dengan keadaan aktual di lapangan, mengetahui hubungan variasi tekanan superheater dengan efisiensi boiler, mengetahui hubungan variasi suhu air umpan dengan efisiensi boiler, mengetahui hubungan variasi jumlah uap yang dihasilkan dengan efisiensi boiler, mengetahui nilai rata-rata yang diperoleh dari boiler seperti steam pressure superheater, temperature 
feed tank, temperature deaerator, temperature outlet steam dan steam flow, serta mengetahui nilai kalor bahan bakar serabut $75 \%$ + cangkang 25\% kelapa sawit. Manfaat dari penelitian ini adalah diharapkan dapat dijadikan acuan pada industri untuk merancang unit Boiler dan menganalisa serta mengoptimasi kinerja unit tersebut.

Boiler atau ketel uap adalah bejana tertutup dimana panas pembakaran dialirkan ke air sampai terbentuk air panas atau steam berupa energi kerja. Air panas atau steam pada tekanan dan suhu tertentu mempunyai nilai energi yang kemudian digunakan untuk mengalirkan panas dalam bentuk energi kalor ke suatu proses. Energi panas dari fluida tersebut selanjutnya digunakan untuk berbagai macam keperluan seperti untuk turbin uap, pemanas ruangan, mesin uap dan lain sebagainya. Secara proses konversi energi, Boiler memiliki fungsi untuk mengkonversi energi kimia yang tersimpan di dalam bahan bakar menjadi energi panas yang tertransfer ke fluida kerja [1].

Komponen utama water tube boiler :

\section{Drum Ketel}

Drum Ketel sebagai "steam separators" dan "purificators" serta sebagai pencampur air agar homogen [4].

\section{Superheater}

Superheater digunakan untuk memanaskan uap jenuh yang terpisah di dalam drum uap. Dalam beberapa bagian uap tersebut hanya dipanaskan sedikit di atas titik saturasi dimana dalam bagian yang lain mungkin dipanaskan sampai temperatur yang signifikan untuk penambahan penyimpanan energi. Bagian superheater ini normalnya diletakkan dalam aliran gas yang lebih panas, depan evaporator [4].

\section{Economizer}

Economizer digunakan untuk pemanasan awal feedwater sebelum uap dipindahkan melalui superheater atau steam outlet dan air keluar melalui blowdown. pada umumnya economizer diletakkan di dalam gas yang lebih dingin pada bagian bawah (down stream) evaporator [4].

\section{Evaporator}

Evaporator merupakan bagian yang berfungsi menaikkan temperatur air mencapai titik didih. Pada evaporator terjadi peristiwa perubahan fase dari cair menjadi uap [4].

\section{Cangkang (Shell)}

Cangkang merupakan limbah dihasilkan dari pemrosesan kernel inti sawit dengan bentuk seperti tempurung kelapa, mempunyai kalor $3500 \mathrm{kkal} / \mathrm{kg}-4100 \mathrm{kkal} / \mathrm{kg}$ [2].

\section{Serabut (Fiber)}

Fiber merupakan limbah sisa perasan buah sawit berupa serabut seperti benang. Bahan ini mengandung protein kasar sekitar 4\% dan serat kasar 36\% (lignin 26\%) serta mempunyai kalor $2637 \mathrm{kkal} / \mathrm{kg}$ - $3998 \mathrm{kkal} / \mathrm{kg}$ [2].

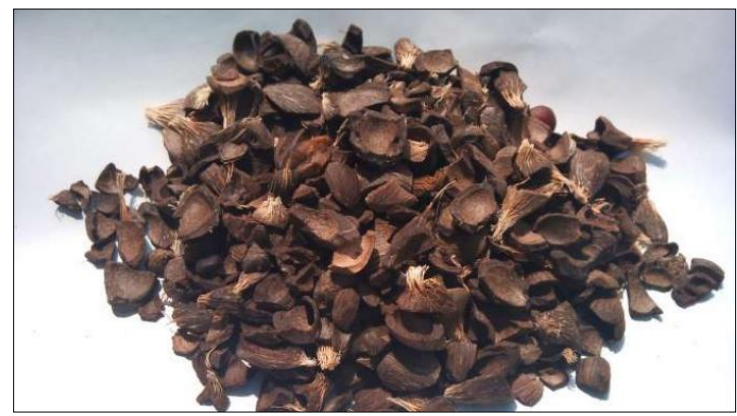

Gambar 1. Cangkang Kelapa Sawit (shell)

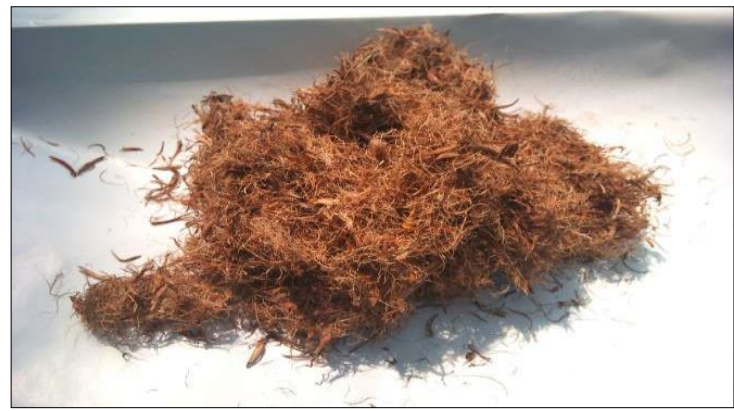

Gambar 2. Serabut Kelapa Sawit (fiber) 
Bejana bertekanan Boiler umumnya menggunakan bahan baja dengan spesifikasi tertentu yang telah ditentukan dalam standard ASME (The American Society of Mechanical Engineers) terutama untuk penggunaan Boiler pada industri - industri besar. Dalam sejarah tercatat berbagai macam jenis material yang digunakan sebagai bahan pembuatan Boiler seperti tembaga, kunigan dan besi cor [2].

Namun bahan - bahan tersebut sudah lama ditinggalkan karena alasan ekonomis dan juga ketahanan material yang sudah tidak sesuai dengan kebutuhan industri. Panas yang diberikan kepada fluida di dalam Boiler berasal dari proses pembakaran dengan berbagai macam jenis bahan bakar yg digunakan seperti kayu, batubara, solar/minyak bumi dan gas. Dengan adanya kemajuan teknologi, energi nuklir pun juga digunakan sebagai sumber panas pada Boiler [6].

\section{Metodologi Penelitian}

Data yang dicantumkan terdiri dari data sheet (base design) Boiler dan data aktual pabrik. Dalam simulasi ini studi kasus yang dilakukan adalah:

1. Menganalisa efisiensi water tube Boiler di Palm Oil Mill.

2. Membandingkan efisiensi Boiler saat baru dengan keadaan sekarang, nilai kalor bahan bakar diuji dengan menggunakan bom calorimeter.

3. Mencari nilai enthalpy menggunakan software ChemicaLogic Steamtab Companion Versi 2.0.

4. Mendapatkan hubungan variasi tekanan superheater dengan efisiensi Boiler.

5. Mendapatkan hubungan variasi suhu air umpan dengan efisiensi Boiler, mendapatkan hubungan variasi jumlah uap yang dihasilkan dengan efisiensi Boiler. Metode yang digunakan adalah metode analisa Water Tube Boiler secara langsung.

Populasi dari penelitian ini adalah limbah biomassa kelapa sawit. Sampel yang diambil dari limbah biomassa kelapa sawit yaitu berupa fiber dan cangkang kelapa sawit. Teknik pengambilan sampel dilakukan secara purposive sampling, dimana didasarkan atas pertimbangan - pertimbangan tertentu dikarenakan jumlahnya secara kuantitatif cukup besar.

\section{Deskripsi Data}

Untuk melengkapi data yang dibutuhkan dalam analisa dan perhitungan diambil sesuai dengan aplikasi penelitian yaitu metode pengambilan data dengan cara pengamatan langsung membaca dan mencatat data-data pada setiap instrumen terhadap sistem dan proses di Boiler. Penulis memperoleh data yang diambil selama kerja praktek dari tanggal 25 Juli - 30 Agustus 2016 di Palm Oil Mill yang akan di pergunakan untuk menyelesaikan permasalahan yang timbul. Data - data tersebut adalah:

Jenis Ketel Uap
Model
Negara Pembuat
Type
Kapasitas Produksi Uap
Tekanan Kerja Maksimal
Tekanan Desain
Tekanan Kerja Normal
Temperatur air masuk ketel
Temperatur Uap Superheater
Temperatur Desain
Permukaan Pemanasan
Temperatur Desain Superheater
Permukaan Superheater
Luas Dapur

: Water Tube Boiler

: BOILERMECH SDN BHD

: Malaysia

: BMWT-0446

: 45 Ton/Jam

: $54 \mathrm{Bar}$

:36 Bar

: 32 Bar

: $98^{\circ} \mathrm{C}$

: $236^{\circ} \mathrm{C}$

: $259^{\circ} \mathrm{C}$

$: 1232 \mathrm{~m}^{2}$

: $435^{\circ} \mathrm{C}$

: $55^{\circ} \mathrm{C}$

$: 18 \mathrm{~m}^{2}$

Tabel 1. Data Spesifikasi Boiler diperoleh langsung dari katalog Boiler

\begin{tabular}{cccc}
\hline $\begin{array}{c}\text { Steam Pressure } \\
\text { Superheater } \\
\text { (bar) }\end{array}$ & $\begin{array}{c}\text { Temperature } \\
\text { Air Umpan } \\
\left({ }^{\circ} \mathbf{C}\right)\end{array}$ & $\begin{array}{c}\text { Temperature Uap } \\
\left({ }^{\circ} \mathbf{C}\right)\end{array}$ & $\begin{array}{c}\text { Produksi Uap } \\
(\text { Kg Uap/jam) }\end{array}$ \\
\hline 31 & 98 & 236 & 45000 \\
\hline
\end{tabular}


Tabel 2. Data 1 Kamis, 25 Agustus 2016

\begin{tabular}{|c|c|c|c|c|c|}
\hline \multirow{2}{*}{ Time $($ Wita) } & Steam Pressure $($ Bar) & Feed Water Temperature $\left({ }^{\circ} \mathbf{C}\right)$ & \multirow{2}{*}{$\begin{array}{c}\text { Temperature Outlet } \\
\text { Steam }\left({ }^{\circ} \mathbf{C}\right)\end{array}$} & $\begin{array}{c}\text { Steam Flow } \\
(\text { Ton/Jam) }\end{array}$ \\
\cline { 2 - 4 } & Superheater & Feed Tank & Deaerator & 236 & 21.8 \\
\hline 13 & 30.6 & 80 & 90 & 236 & 28.7 \\
\hline 14 & 30.7 & 88 & 90 & 236 & 27.3 \\
\hline 15 & 30.6 & 88 & 96 & 236 & 27.6 \\
\hline 16 & 31.2 & 90 & 98 & 236 & 25.2 \\
\hline 17 & 30.9 & 90 & 98 & 236 & 27.7 \\
\hline 18 & 30.8 & 90 & 98 & 236 & 28.2 \\
\hline 19 & 30.3 & 90 & 98 & 236 & 28.7 \\
\hline 20 & 30.2 & 92 & 98 & $\mathbf{2 3 6}$ & $\mathbf{2 6 . 9}$ \\
\hline rata-rata & $\mathbf{3 0 . 6 6 2 5}$ & $\mathbf{8 8 . 5}$ & $\mathbf{9 5 . 7 5}$ & & \\
\hline
\end{tabular}

Tabel 3. Data 2 Jumat, 26 Agustus 2016

\begin{tabular}{|c|c|c|c|c|c|}
\hline \multirow{2}{*}{ Time (Wita) } & Steam Pressure $($ Bar) & Feed Water Temperature $\left({ }^{\circ} \mathbf{C}\right)$ & \multirow{2}{*}{$\begin{array}{c}\text { Temperature Outlet } \\
\text { Steam }\left({ }^{\circ} \mathbf{C}\right)\end{array}$} & $\begin{array}{c}\text { Steam Flow } \\
(\text { Ton/Jam) }\end{array}$ \\
\cline { 2 - 4 } & Superheater & Feed Tank & Deaerator & 236 & 18.2 \\
\hline 13 & 31 & 90 & 96 & 236 & 19.8 \\
\hline 14 & 30.9 & 90 & 96 & 236 & 22.5 \\
\hline 15 & 30.9 & 90 & 98 & 236 & 19 \\
\hline 16 & 30.8 & 90 & 98 & 236 & 21.2 \\
\hline 17 & 29.6 & 90 & 98 & 236 & 24.8 \\
\hline 18 & 31.1 & 92 & 98 & 236 & 2.4 \\
\hline 19 & 30.9 & 92 & 98 & 236 & 24.8 \\
\hline 20 & 30.7 & 92 & 98 & $\mathbf{2 3 6}$ & $\mathbf{2 2 . 2 1 2 5}$ \\
\hline rata-rata & $\mathbf{3 0 . 7 3 7 5}$ & $\mathbf{9 0 . 7 5}$ & $\mathbf{9 7 . 5}$ & & \\
\hline
\end{tabular}

Tabel 4. Data 3 Sabtu, 27 Agustus 2016

\begin{tabular}{|c|c|c|c|c|c|}
\hline \multirow{2}{*}{ Time $($ Wita) } & Steam Pressure (Bar) & \multicolumn{2}{|c|}{ Feed Water Temperature $\left({ }^{\circ} \mathbf{C}\right)$} & \multirow{2}{*}{$\begin{array}{c}\text { Temperature Outlet } \\
\text { Steam }\left({ }^{\circ} \text { C) }\right.\end{array}$} & $\begin{array}{c}\text { Steam Flow } \\
(\text { Ton/Jam) }\end{array}$ \\
\cline { 2 - 4 } & Superheater & Feed Tank & Deaerator & 236 & 27.1 \\
\hline 13 & 30.8 & 90 & 98 & 236 & 25.9 \\
\hline 14 & 30.8 & 90 & 98 & 236 & 26.9 \\
\hline 15 & 30.5 & 92 & 98 & 236 & 25.6 \\
\hline 16 & 30.4 & 92 & 98 & 236 & 25.1 \\
\hline 17 & 31.2 & 92 & 98 & 236 & 26 \\
\hline 18 & 30.8 & 92 & 98 & 236 & 27 \\
\hline 19 & 30.4 & 92 & 98 & 236 & 25.6 \\
\hline 20 & 30.7 & $\mathbf{9 1 . 5}$ & $\mathbf{9 8}$ & $\mathbf{2 3 6}$ & $\mathbf{2 6 . 1 5}$ \\
\hline
\end{tabular}

Tabel 5. Data 4 Minggu, 28 Agustus 2016

\begin{tabular}{|c|c|c|c|c|c|}
\hline \multirow{2}{*}{ Time $($ Wita) } & Steam Pressure (Bar) & Feed Water Temperature $\left({ }^{\circ} \mathbf{C}\right)$ & \multirow{2}{*}{$\begin{array}{c}\text { Temperature Outlet } \\
\text { Steam }\left({ }^{\circ} \text { C) }\right.\end{array}$} & $\begin{array}{c}\text { Steam Flow } \\
(\text { Ton/Jam) }\end{array}$ \\
\cline { 2 - 4 } & Superheater & Feed Tank & Deaerator & 236 & 28.2 \\
\hline 13 & 30.7 & 92 & 98 & 236 & 27.6 \\
\hline 14 & 30.4 & 92 & 98 & 236 & 26.3 \\
\hline 16 & 30.6 & 92 & 98 & 236 & 28 \\
\hline 17 & 30.8 & 92 & 98 & 236 & 26.9 \\
\hline 18 & 30.8 & 92 & 98 & 236 & 26.2 \\
\hline 19 & 31 & 92 & 98 & 236 & 25.9 \\
\hline 20 & 30.7 & 92 & 98 & 236 & 27.8 \\
\hline rata-rata & 30.3 & $\mathbf{9 2}$ & $\mathbf{9 8}$ & $\mathbf{2 3 6}$ & $\mathbf{2 7 . 1 1 2 5}$ \\
\hline
\end{tabular}


Tabel 6. Data 5 Senin, 29 Agustus 2016

\begin{tabular}{|c|c|c|c|c|c|}
\hline \multirow{2}{*}{ Time $($ Wita) } & Steam Pressure (Bar) & \multicolumn{2}{|c|}{ Feed Water Temperature $\left({ }^{\circ}\right.$ C) } & \multirow{2}{*}{$\begin{array}{c}\text { Temperature Outlet } \\
\text { Steam }\left({ }^{\circ} \text { C) }\right.\end{array}$} & $\begin{array}{c}\text { Steam Flow } \\
(\text { Ton/Jam) }\end{array}$ \\
\cline { 2 - 5 } & Superheater & Feed Tank & Deaerator & 236 & 20 \\
\hline 13 & 30.9 & 80 & 98 & 236 & 27.9 \\
\hline 14 & 30.4 & 88 & 98 & 236 & 32 \\
\hline 15 & 27.8 & 89 & 98 & 236 & 28.9 \\
\hline 16 & 30.4 & 89 & 98 & 236 & 26.6 \\
\hline 18 & 30.3 & 89 & 98 & 236 & 27.8 \\
\hline 19 & 30.5 & 89 & 98 & 236 & 28.2 \\
\hline 20 & 30.7 & 89 & 98 & 236 & 28.3 \\
\hline rata-rata & 30.9 & $\mathbf{8 7 . 7 5}$ & $\mathbf{9 8}$ & $\mathbf{2 3 6}$ & $\mathbf{2 7 . 4 6 2 5}$ \\
\hline
\end{tabular}

Tabel 7. Data 6 Kamis s/d Senin 2016

\begin{tabular}{|c|c|c|c|c|c|}
\hline \multirow{2}{*}{ Hari/Tanggal } & Steam Pressure $($ Bar $)$ & \multicolumn{2}{|c|}{ Feed Water Temperature $\left({ }^{\circ} \mathbf{C}\right)$} & $\begin{array}{c}\text { Temperature Outlet } \\
\text { Steam }\left({ }^{\circ} \mathbf{C}\right)\end{array}$ & $\begin{array}{c}\text { Steam Flow } \\
(\text { Ton/Jam) }\end{array}$ \\
\cline { 2 - 4 } & Superheater & Feed Tank & Deaerator & 236 & 26.9 \\
\hline Kamis & 30.6625 & 88.5 & 95.75 & 236 & 22.2125 \\
\hline Jumat & 30.7375 & 90.75 & 97.5 & 236 & 26.15 \\
\hline Sabtu & 30.7 & 91.5 & 98 & 236 & 27.1125 \\
\hline Minggu & 30.6625 & 92 & 98 & 236 & 27.4625 \\
\hline Senin & 30.2375 & 87.75 & 98 & $\mathbf{2 3 6}$ & $\mathbf{2 5 . 9 6 7 5}$ \\
\hline rata-rata & $\mathbf{3 0 . 6}$ & $\mathbf{9 0 . 1}$ & $\mathbf{9 7 . 4 5}$ & \\
\hline
\end{tabular}

Pada pengujian ini, variabel pengujian untuk mendapatkan nilai kalor bahan bakar yaitu High Heating Value (HHV) dan Low Heating Value (LHV). Skala rasio yang diambil adalah serabut kelapa sawit murni, cangkang kelapa sawit murni dan perbandingan serabut kelapa sawit $75 \%$ dengan cangkang kelapa sawit $25 \%$.

\section{Rumus - rumus yang Digunakan}

1. Nilai kalor atas (HHV) dapat dihitung dengan rumus:

$\mathrm{HHV}=\left(\mathrm{T}_{2}-\mathrm{T}_{1}-\mathrm{T}_{\mathrm{kp}}\right) \times \mathrm{C}_{\mathrm{v}}(\mathrm{kJ} / \mathrm{kg})$

2. Nilai kalor bawah (LHV) dapat dihitung dengan rumus:

$\mathrm{LHV}=\mathrm{HHV}-3240(\mathrm{~kJ} / \mathrm{kg})$

3. Bila dilakukan pengujian n kali pengujian, maka:

$H H V_{\text {rata - rata }}=\frac{\sum_{i=1}^{n} H H V}{n}\left(\frac{\mathrm{kJ}}{\mathrm{kg}}\right)$

$\mathrm{LHV}_{\text {rata }- \text { rata }}=\mathrm{HHV}_{\text {rata }- \text { rata }}-3240(\mathrm{~kJ} / \mathrm{kg})$

Dimana:

$\mathrm{T}_{1} \quad$ = Suhu air dingin sebelum dinyalakan $\left({ }^{\circ} \mathrm{C}\right)$

$\mathrm{T}_{2}=$ Suhu air dingin setelah penyalaan $\left({ }^{\circ} \mathrm{C}\right)$

$\mathrm{T}_{\mathrm{kp}}=$ kenaikan suhu akibat kawat menyala $0,05^{\circ} \mathrm{C}$

$\mathrm{C}_{\mathrm{v}}=$ Panas jenis bom kalorimeter $\left(73529,6 \mathrm{~kJ} / \mathrm{kg} .{ }^{\circ} \mathrm{C}\right)$

4. Konsumsi bahan bakar $\left(\mathrm{W}_{\mathrm{f}}\right)$

Mencari jumlah bahan bakar yang tersedia di Palm Oil Mill, untuk bahan bakar fiber 13\% dari kapasitas pabrik dan bahan bakar cangkang $6 \%$ dari kapasitas pabrik. Sehingga:

- $\%$ fiber $=\%$ fiber $\mathrm{x}$ kapasitas pabrik

- $\%$ cangkang $=\%$ cangkang $\mathrm{x}$ kapasitas pabrik

- $\mathrm{W}_{\mathrm{f}}=75 \%$ fiber $+25 \%$ cangkang

5. Efisiensi Water Tube Boiler

$$
\eta b=\frac{W s(h g-h f)}{W f \times \text { LHVrata }- \text { rata }} \times 100 \%
$$

Dimana:

Ws = Produksi Uap Boiler P.T. Indonesia Plantation Synergy (kg uap/jam)

hg = Entalphy superheated/subcooled $(\mathrm{kJ} / \mathrm{kg})$

hf $=$ Entalphy saturated $(\mathrm{kJ} / \mathrm{kg})$

Wf = Konsumsi bahan bakar $(\mathrm{kg} / \mathrm{jam})$

$\mathrm{LHV}_{\text {rata }- \text { rata }}=$ Low Heating Value rata - rata $(\mathrm{kg} / \mathrm{jam})$ 


\section{Diagram Alir Penelitian}

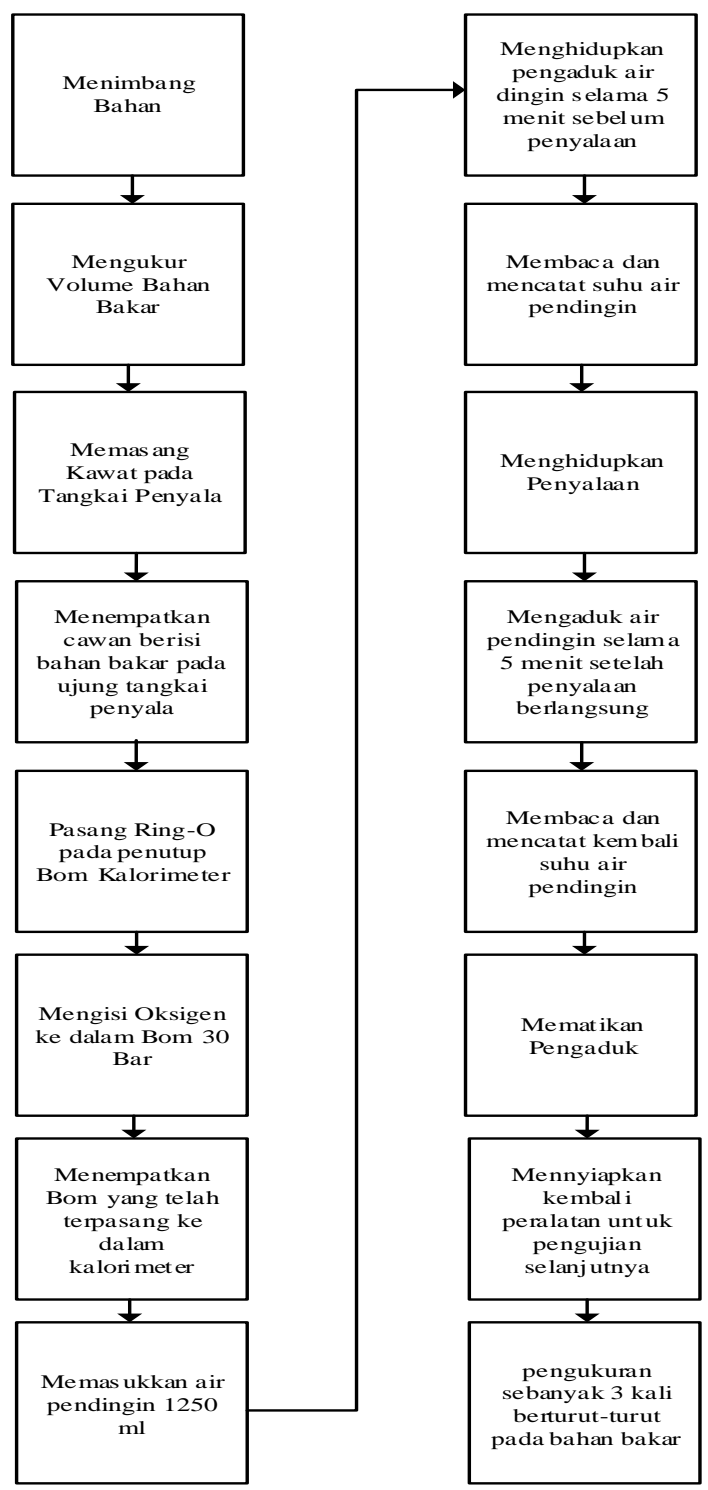

Gambar 3. Diagram alir penelitian

\section{Hasil dan Pembahasan}

Uji laboratorium biasanya digunakan untuk mengkaji sifat dan kualitas bahan bakar. Jadi untuk melakukan pembakaran diperlukan tiga unsur yaitu:

- Bahan bakar

- Oksigen

- Suhu untuk memulai pembakaran

Panas (kalor) yang timbul karena pembakaran bahan bakar tersebut disebut hasil pembakaran atau nilai kalor bahan bakar (Heating Value).

\section{Nilai Kalor Bahan Bakar (Heating Value)}

Nilai kalor (Heating Value) adalah banyaknya energi panas yang diperoleh dari hasil pembakaran $1 \mathrm{~kg}$ bahan bakar. Nilai kalor ini dibagi menjadi:

1. Nilai kalor tinggi atau High Heating Value (HHV) adalah banyaknya kalor yang dihasilkan pada proses pembakaran $1 \mathrm{~kg}$ bahan bakar, tanpa adanya kandungan air pada bahan bakar.

2. Nilai kalor rendah atau Low Heating Value

(LHV) adalah banyaknya kalor yang dihasilkan pada proses pembakaran $1 \mathrm{~kg}$ bahan bakar dan sebagian dimanfaatkan untuk penguapan sehingga kandungan air pada bahan bakar akan habis. 
Tabel 8. Hasil analisa kalor bahan bakar fiber murni

\begin{tabular}{|c|c|c|c|c|}
\hline No. & $\mathrm{T}_{1}\left({ }^{\circ} \mathrm{C}\right)$ & $\mathrm{T}_{2}\left({ }^{\circ} \mathrm{C}\right)$ & $\mathrm{HHV}(\mathrm{kJ} / \mathrm{kg})$ & LHV $(\mathrm{kJ} / \mathrm{kg})$ \\
\hline 1. & 26,13 & 26,35 & 12500,032 & 9260,032 \\
\hline 2. & 26,49 & 26,74 & 14705,92 & 11465,92 \\
\hline 3. & 26,91 & 27,18 & 16176,512 & 12936,512 \\
\hline \multicolumn{3}{|c|}{ Rata-rata } & 14460,8213 & 11220,8213 \\
\hline
\end{tabular}

Tabel 9. Hasil analisa kalor bahan bakar cangkang murni

\begin{tabular}{|c|c|c|c|c|}
\hline No. & $\mathrm{T}_{1}\left({ }^{\circ} \mathrm{C}\right)$ & $\mathrm{T}_{2}\left({ }^{\circ} \mathrm{C}\right)$ & $\mathrm{HHV}(\mathrm{kJ} / \mathrm{kg})$ & $\mathrm{LHV}(\mathrm{kJ} / \mathrm{kg})$ \\
\hline 1. & 26,71 & 27,08 & 23529,472 & 20289,472 \\
\hline 2. & 27,24 & 27,61 & 23529,472 & 20289,472 \\
\hline 3. & 27,82 & 28,19 & 23529,472 & 20289,472 \\
\hline \multicolumn{3}{|c|}{ Rata-rata } & 23529,472 & 20289,472 \\
\hline
\end{tabular}

Tabel 10. Hasil analisa kalor bahan bakar fiber $75 \%$ + cangkang $25 \%$

\begin{tabular}{|c|c|c|c|c|}
\hline No. & $\mathrm{T}_{1}\left({ }^{\circ} \mathrm{C}\right)$ & $\mathrm{T}_{2}\left({ }^{\circ} \mathrm{C}\right)$ & $\mathrm{HHV}(\mathrm{kJ} / \mathrm{kg})$ & LHV $(\mathrm{kJ} / \mathrm{kg})$ \\
\hline 1. & 26,93 & 27,27 & 21323,584 & 18083,584 \\
\hline 2. & 27,44 & 27,78 & 21323,584 & 18083,584 \\
\hline 3. & 27,94 & 28,27 & 20588,288 & 17348,288 \\
\hline \multicolumn{3}{|c|}{ Rata-rata } & 21078,4853 & 17838,4853 \\
\hline
\end{tabular}

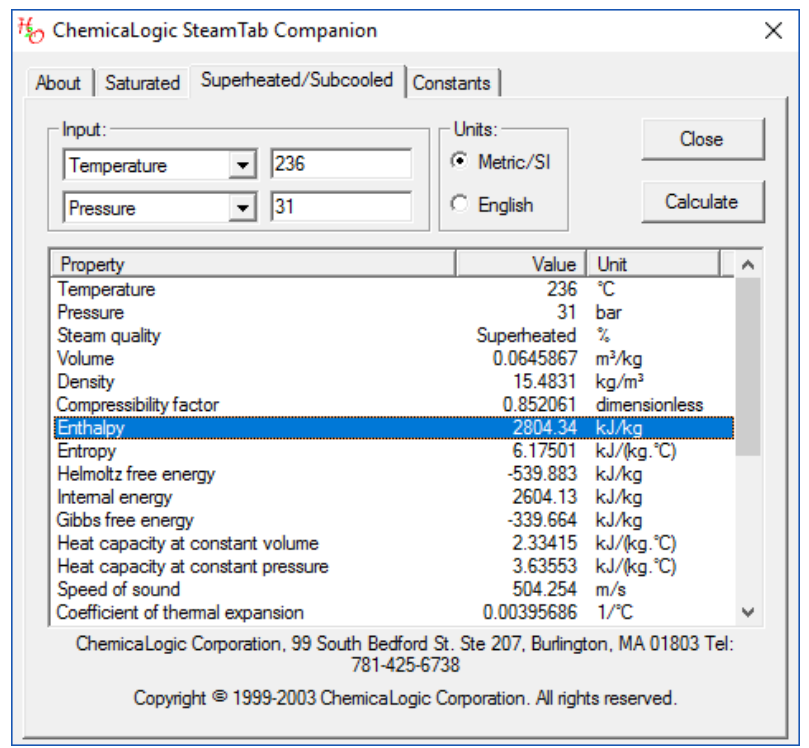

Gambar 4. Contoh simulasi mencari entalphy pada $\mathrm{P}=31$ bar dan $\mathrm{T}=236^{\circ} \mathrm{C}$ menggunakan ChemicaLogic Steamtab Companion Versi 2.0. 


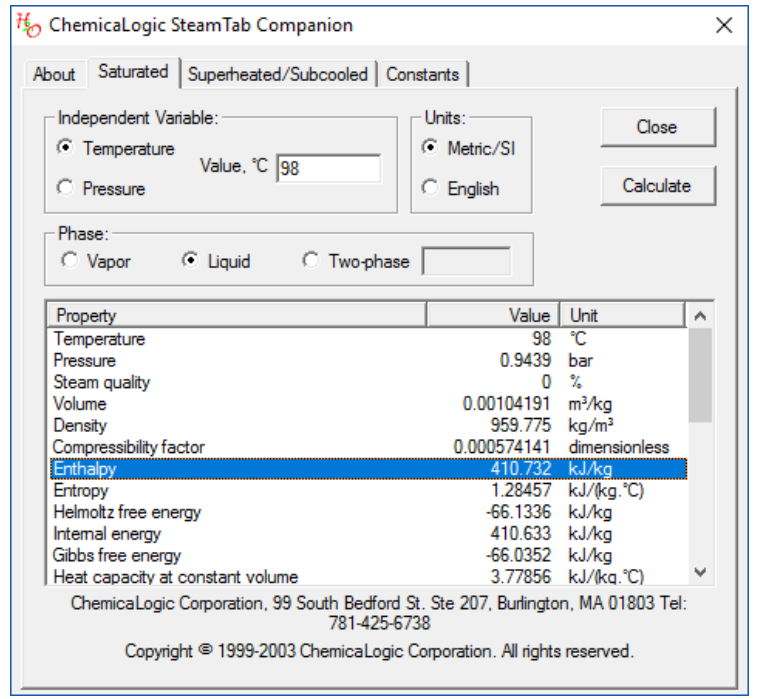

Gambar 5. Contoh simulasi mencari entalphy pada $\mathrm{T}=98^{\circ} \mathrm{C}$ menggunakan ChemicaLogic Steamtab Companion Versi 2.0.

Tabel 11. Data Efisiensi Boiler Saat Baru

\begin{tabular}{ccccc}
\hline $\begin{array}{c}\text { Entalpy Uap } \\
(\mathrm{kJ} / \mathrm{kg})\end{array}$ & $\begin{array}{c}\text { Tekanan Superheater } \\
(\mathrm{Bar})\end{array}$ & $\begin{array}{c}\text { Suhu Air Umpan } \\
\left({ }^{\circ} \mathrm{C}\right)\end{array}$ & $\begin{array}{c}\text { Produksi Uap } \\
(\mathrm{kg} \mathrm{Uap} / \mathrm{jam})\end{array}$ & $\begin{array}{c}\text { Efisiensi Boiler } \\
(\%)\end{array}$ \\
\hline 2804,34 & 31 & 98 & 45000 & $89,45 \%$ \\
\hline
\end{tabular}

Dengan menggunakan 5 data yang dikumpulkan selama 5 hari berturut - turut pada proses Boiler berbahan bakar fiber dan cangkang di PT. Indonesia Plantation Synergy maka didapatkan perhitungan sebagai berikut:

Tabel 12. Hubungan Enthalpy Uap, Tekanan Superheater, Suhu Air Umpan, dan Produksi Uap dengan Efisiensi Boiler menggunakan 5 data aktual pada lapangan proses di Boiler

\begin{tabular}{ccccc}
\hline $\begin{array}{c}\text { Entalpy Uap } \\
(\mathrm{kJ} / \mathrm{kg})\end{array}$ & $\begin{array}{c}\text { Tekanan } \\
\text { Superheater } \\
(\text { Bar })\end{array}$ & $\begin{array}{c}\text { Suhu Air Umpan } \\
\left({ }^{\circ} \mathrm{C}\right)\end{array}$ & $\begin{array}{c}\text { Produksi Uap } \\
(\mathrm{kg} \text { Uap/jam })\end{array}$ & $\begin{array}{c}\text { Efisiensi Boiler } \\
(\%)\end{array}$ \\
\hline 2806,06 & 30,7375 & 97,5 & 22212,5 & $44,23 \%$ \\
\hline 2806,3 & 30,7000 & 98 & 26150 & 52,02 \\
\hline 2806,54 & 30,6625 & 95,75 & 26900 & 53,73 \\
\hline 2806,54 & 30,6625 & 98 & 27112,5 & 53,94 \\
\hline 2809,28 & 30,2375 & 98 & 27462,5 & 54,7 \\
\hline
\end{tabular}

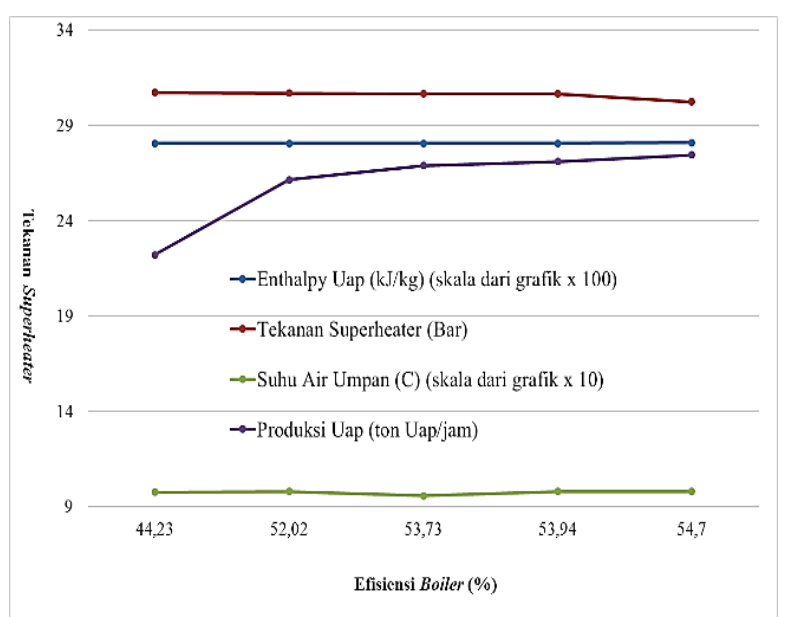

Gambar 6. Grafik Hubungan Enthalpy Uap, Tekanan Superheater, Suhu Air Umpan, dan Produksi Uap dengan Efisiensi Boiler 
Berdasarkan gambar 6, dapat dilihat bahwa Hubungan Enthalpy Uap, Tekanan Superheater, Suhu Air Umpan, dan Produksi Uap dengan Efisiensi Boiler. Dimana efisiensi boiler sebesar 44,23\% dengan nilai enthalpy uap sebesar $2806,06 \mathrm{~kJ} / \mathrm{kg}$, tekanan superheater sebesar 30,7375 bar, suhu air umpan $97,5^{\circ} \mathrm{C}$ dan produksi uap $22212,5 \mathrm{~kg}$ uap/jam, efisiensi boiler sebesar 52,02\% dengan nilai enthalpy uap sebesar 2806,3 kJ/kg, tekanan superheater sebesar 30,7000 bar, suhu air umpan $98^{\circ} \mathrm{C}$ dan produksi uap $26150 \mathrm{~kg}$ uap/jam, efisiensi boiler sebesar 53,73\% dengan nilai enthalpy uap sebesar $2806,54 \mathrm{~kJ} / \mathrm{kg}$, tekanan superheater sebesar 30,6625 bar, suhu air umpan $95,75^{\circ} \mathrm{C}$ dan produksi uap $26900 \mathrm{~kg}$ uap/jam, efisiensi boiler sebesar 53,94\% dengan nilai enthalpy uap sebesar $2806,54 \mathrm{~kJ} / \mathrm{kg}$, tekanan superheater sebesar 30,6625 bar, suhu air umpan $98^{\circ} \mathrm{C}$ dan produksi uap 27112,5 kg uap/jam, efisiensi boiler sebesar 54,7\% dengan nilai enthalpy uap sebesar 2809,28 $\mathrm{kJ} / \mathrm{kg}$, tekanan superheater sebesar 30,2375 bar, suhu air umpan $98^{\circ} \mathrm{C}$ dan produksi uap 27462,5 kg uap/jam.

\section{Kesimpulan dan Saran}

\section{Kesimpulan}

Dari simulasi ini dapat disimpulkan analisa kinerja dari Water Tube Boiler yaitu:

1. Nilai efisiensi water tube boiler terendah yang dihasilkan sebesar $44,23 \%$ dan nilai efisiensi water tube boiler tertinggi yang dihasilkan sebesar $54,7 \%$.

2. Membandingkan efisiensi boiler saat baru dengan keadaan sekarang mengalami penurunan, efisiensi boiler saat baru sebesar $89,45 \%$ sedangkan efisiensi boiler dengan keadaan saat ini mengalami penurunan menjadi sebesar $44,23 \%-54,7 \%$.

3. Hubungan variasi tekanan superheater dengan efisiensi boiler tidak konstan melainkan tidak teratur atau naik turun.

4. Hubungan variasi suhu air umpan dengan efisiensi boiler tidak konstan melainkan tidak teratur atau naik turun.

5. Hubungan variasi jumlah uap yang dihasilkan dengan efisiensi boiler relatif konstan naik.

6. Nilai rata - rata yang diperoleh dari boiler untuk:

- Steam Pressure Superheater: 30,6 bar

- Temperatur Feed Tank : : 90, $1^{\circ} \mathrm{C}$

- Temperatur Deaerator $\quad: 97,45^{\circ} \mathrm{C}$

- Temperatur Outlet Steam : $236^{\circ} \mathrm{C}$

- Steam Flow : 25,9675 ton uap/jam

7. Nilai Kalor bahan bakar serabut $75 \%$ + cangkang $25 \%$ kelapa sawit:

- Nilai Kalor Pembakaran Tinggi (HHV) : $21078,4853 \mathrm{~kJ} / \mathrm{kg}$

- Nilai Kalor Pembakaran Rendah (LHV): 17838,4853 kJ/kg

\section{Saran}

Adapun saran - saran yang dapat diajukan pada Palm Oil Mill maupun pembaca untuk menyempurnakan penelitian tentang analisa efisiensi water tube boiler berbahan bakar fiber dan cangkang yaitu:

1. Untuk meningkatkan efisiensi boiler lakukan pengecekan secara berkala dan pembersihan pipa - pipa boiler secara berkala.

2. Untuk meningkatkan efisiensi boiler kandungan air yang berlebihan pada bahan bakar untuk diperhatikan.

3. Temperatur air umpan lebih diperhatikan.

4. Untuk mengurangi penurunan efisiensi boiler lakukan pengontrolan terhadap kandungan air pada feed water sebelum masuk ke deaerator.

5. Lakukan pengecekan katup - katup yang ada pada boiler, harus diperhatikan bahwa semua katup dapat berfungsi dengan baik.

\section{Daftar Pustaka}

[1] Djokosetyardjo, I. R. M. J., 2003, Ketel Uap, Cetakan Kelima, Pradnya Paramita. Jakarta.

[2] Febijanto, Irham, 2016, Journal, Kajian Teknis dan Keekonomian Pembangkit Tenaga Biomassa Sawit, Jakarta.

[3] James J. Jackson, 1980, Steam Boiler Operation, Prenticehall, Inc.

[4] Holman, J. P., 1981, Heat Transfer, Mc Graw Hill Book Inc., Edisi ke 5, Jakarta.

[5] Mars G. Fontana “Corossion Engineering” Third Edition, McGraw - Hill Book Company, New York, 1986.

[6] M. J. Djokosetyardjo, 1993, Ketel Uap, P. T. Pradnya Paramita.

[7] Silalahi Abel, 1977, Dasar - dasar Ketel Uap, ITN Malang

[8] Yunus, Asyari D. Ketel Uap (Steam Boiler). Jakarta: Teknik Mesin Universitas Darma Persada. 